\title{
The Impact of Stock Price and Real Estate Price Shocks on Consumption: The Thai Experience
}

\author{
Dalina Amonhaemanon ${ }^{1}$ \\ ${ }^{1}$ Prince of Songkla University, Trang campus, Thailand \\ Correspondence: Dalina Amonhaemanon, Prince of Songkla University, Trang campus, Thailand. E-mail: \\ dalina.a@psu.ac.th
}

Received: December 1, 2014

Accepted: December 15, 2014

Online Published: January 18, 2015

doi:10.5430/ijfr.v6n1p137

URL: http://dx.doi.org/10.5430/ijfr.v6n1p137

\begin{abstract}
This paper compares the effects of real house price and real stock price shocks on consumption decisions in Thailand over the period 1993 to 2014 using a Vector Autoregressive (VAR) approach. The sample comprises quarterly, seasonally adjusted Thai data on consumption, real house price and real stock price. The results indicate that disturbance originating from consumption itself caused the greatest variability to future consumption: it contributes up to 76.43 percent variability one quarter ahead, GDP shocks explain between 17 and 19 percent of the variance of consumption depending on the forecast horizons- with higher shares explained at longer forecast horizons. While, townhouse price shocks explain about 5 percent and single house price shocks explain about 0.47 to 0.51 percent of the variance of consumption, stock price shocks explain about 0.2 to 0.21 percent of the variance of consumption. To explaining variations of consumption, the housing market is more important than stock market for Thailand case.
\end{abstract}

Keywords: consumption, permanent income hypothesis, Thailand

\section{Introduction}

Consumption plays a dominant role in macro and financial economics. In asset pricing e.g., economic agents derive utility from consumption and hence investors will decide how much they consume in each period, how much they save and which (risky) assets they want to hold. The uncertain return on the risky savings leads, even with a constant endowment in each period, to an uncertain available future wealth and hence to a stochastic consumption patterns over time. From investment perspectives, both stocks and housing are considered as alternative investment assets. Due to their inherent nature, assets exposed different liquidity and risky characteristics. Thus, investors would hold a mix of property assets and equities to optimize their portfolios (Hui, 2009).

There appears to be a lot of uncertainty upon the effects of factors on long-term asset prices, such as those of equity, real estates (Caporale \& Sousa, 2011). The uncertainty of returns on the risky savings leads, even with a constant endowment in each period, to the fluctuations of the available future wealth and hence, to a stochastic consumption patterns of individuals over time. The public view and many economists believe that higher consumption can drive the economic growth because private consumption constitutes the largest share of GDP. This implies that factor that impacts on consumption, e.g., households' wealth, are also important for the economic growth. A number of empirical studies suggest that, among others, changes in financial wealth and housing wealth are closely related to trend movements in household consumption and domestic demand. Such studies include, e.g., Case and Quigley (2005), Campbell and Cocco (2005), Chen (2006a) and Lugwig and Slok (2004). Moreover, most of these studies found that the rising in housing wealth was the primary reason for the increasing in consumption.

Thailand economy is not the exceptional case where consumption is one of the main drivers for the aggregate demand. In Thailand, the private consumption has, in recent years, been counted for about 70\% of GDP (reference). Moreover, housing generally shares the largest part of the households' portfolio (reference), which could indicate that the housing price fluctuations can influence the housing market and the long-run economic growth. As such, studying the linkages between the households' consumption and assets in Thailand would be greatly important.

The impact of wealth changes on consumption is likely to vary according to the type of wealth. This paper focuses on the two wealth components; stock market and housing wealth because of two reasons. First, the liquidity of stock and housing market wealth differs significantly. Until recently it has been easier to directly realize equity gains than 
house price gains, since equities are divisible and traded in liquid markets. However, it is increasingly easy to borrow against housing wealth through home equity loans. Moreover, rising housing prices may affect consumption not only through higher realized home values, but also by the household's ability to refinance a mortgage home equity loans based on higher property values. This may, in fact, bolster the sensitivity of consumption to housing price movements. Second, the equity prices are more volatile than house prices, households may find it more difficult to assess whether a change in stock wealth is permanent or temporary. Therefore, they are likely to be more cautious borrowing against increases in equity wealth than housing wealth, suggesting a higher impact of increases in housing wealth on consumption (Bayoumi \& Edison, 2003). All reasons imply that changes in housing wealth have a larger effect on consumption.

Since residential property in Thailand is almost a single most important component of the assets on the households' portfolio (Graph1), the wealth position of households is interlinked with housing values. Comparing the structure of total assets in 2006 and 2010 indicates that Thai households still rely invest more in terms of real estate than on capital markets (Graph1). This is consistent with the result that housing wealth shock has more impact to consumption than stock price shock. A problem facing the Thai's economy is whether the unexpected shock in stock market and property markets has implications for consumption. According to the permanent income hypothesis, any household's consumption responds to changes only in permanent unanticipated change in wealth, but very little to transitory. This study focus on the housing and stock markets wealth effects on consumption as fluctuations in these two markets accounted for a dominant part of unanticipated change in wealth so unexpected house price and stock price rise should stimulate consumption. Housing good have a dual nature of commodities and of investment asset that make housing market unlike the market for other goods and service (Kenny, 1998). Shocks in the rate of housing price appreciation can also affect consumption when an increase in the house prices today is not expected to be exactly matched by the same increase in the future, and generating a wealth effect (Contreras \& Nichols, 2009).

Whether house price appreciation shocks affect consumption and whether they have permanent and transitory components are empirical questions. In a world with efficient markets, shocks to house price appreciation would be arbitraged away in the market. But in a market with heterogeneous consumers and sub-markets like the housing market, those arbitrage possibilities may take time to disappear, and price bubbles might occur, causing the shocks in price appreciation to be perceived as persistent. The extent to which significant housing appreciation might support higher consumption during a housing boom and the extent to which consumption might fall when the home values decline (Contreras \& Nichols, 2009). The recurring financial crises in many part of the world have raised concern that the asset markets can also have adverse bearings on economic performance (Hui, 2009). In this regards, the 1997/1998 Asian crisis, which started in Thailand and propagated to other Asian economies, is a good example. During the pre-Asian financial crisis years, robust macroeconomic developments was claimed to have played a crucial role in stimulating residential housing markets, resulting in a rapid ascension of house prices which peaked in 1996. By the end of 1996, outstanding property loans reached 863 billion baht compared to 135 billion baht in 1989, increasing to around 19 percent of GDP. The boom of the real estates or the housing sector is one of the key factors lead Thailand to the bubble economy. Thailand economic crash in 1997, the result showed that the real estate and housing market in Thailand has been in a severe downturn (Richupan, 1999). Any downturn in the market could lead to a reduction of consumption and then led to a major economic slump (Akin, 2008). Therefore, the sharp decline in housing prices in the past several years has led to weak economic activity (Chen, 2006a). The subsequent collapse in the stock market has led the country into its most severe economic crisis because the housing sector and the financial sector are closely interrelated (Ibrahim, Padli, \& Baharom). As in many other economies, in Thailand, wealth is being stored to a large extent in real estate and in stocks. The housing sector is not only recognized as one of the main factors for domestic growth, but it is also closely connected to the overall economy (Carroll, Otsuka, \& Slacalek, 2011). During 1993-2011, the real estate industry in Thailand constituted about $62.48 \%$ price/GDP per capita. Moreover, a record share in 2011 from Bank of Thailand, home equity has been the largest component of household net worth.

The main objective of the study is to analyze the impact of housing prices and stock prices shock on consumption. The theoretical framework should allow for uncertainty as the sources of capital income, the prices change in housing is assumed to have the bigger impact on consumption than the stock price shock. With this objective, we investigate two specific issues related to Thailand's economy. First, does the consumption behavior in Thailand satisfy the permanent income hypothesis? Secondly, how do consumers in Thailand react to unanticipated change in housing and financial wealth? 


\section{Literature Survey}

\subsection{Theory of Permanent Income Hypothesis}

This section presents an overview of the theoretical background of our empirical work. The PIH is essentially a theory about the relationship between permanent income and consumption. The main objective should distinguish between the two types of income expectation. One is a long-run prediction of income where the horizon may extend over much, or all, of the household's life span. The other is short-run prediction of income, extending no more than a few years into the future. The PIH of consumption will provide a more accurate description of consumer in the real economy shocks that are of a temporary or transitory income or short-run prediction of income should impact less than long-run prediction of income. An important rule of the PIH is that consumers do not focused about the past; they only pay attention on the present and the future. Furthermore, the kind of the shocks can be important: consumers will react different between permanent shock and transitory shock. The permanent shock will be reacting stronger than transitory shock or we can say imply that consumption will be response more strongly to permanent rather than transitory shock.

The central idea of the PIH is that since people base their consumption on the permanent income or the future expected. Permanent income is determined by current income and people's expectations about future income and only changes in permanent income affect planned consumption (Friedman, 1957). PIH is the annuity value of the sum of human wealth and nonhuman wealth. Friedman (1957) stated, "Current consumption may be expected to depend not only on total permanent income and the interest rate, but also on the fraction of permanent income derived from nonhuman wealth. The crucial variable is the ratio for nonhuman wealth to permanent income, not the absolute amount of nonhuman wealth".

The main different between LCH and PIH concerns the length of the planning period. LCH recognized the finite life of households and PIH concerned at this period as infinite. However, instead of focusing on the age of the individuals, the PIH focuses on the type of income that the individuals receive (Friedman, 1957). Besides, while the $\mathrm{LCH}$ assumes that income has a regular path along the life of an individual, the PIH emphasizes on the fact that income changes due to temporary and random shock. Nevertheless, consumers decide how much to consume from their future prospects; if no uncertainty, consumers try to have smooth consumption over time.

The PIH decomposes both consumption and income of individuals into two components; the permanent part and the transitory part. Current income is the sum of two components: a permanent component $\left(Y_{p}\right)$ and a transitory component $\left(Y_{t}\right)$,

$$
Y=Y_{p}+Y_{t}
$$

The permanent income is determined by current income and individual's expectation about future income. The transitory component is to be interpreted as factors that are likely to be treated by the unit affected as accidental or chance occurrences.

Similarly, let $C$ represent a consumer unit's expenditures for some time period equal the sum of a permanent component $\left(C_{p}\right)$ and a transitory component $\left(C_{t}\right)$, so that

$$
C=C_{p}+C_{t}
$$

The basic perception that individuals would wish to smooth their consumption and do not let it fluctuate with short run fluctuations in income. Friedman assumed hypothesized that individuals base their consumption on a longer-term view of their measured income. In short, the PIH formally states that consumption of an individual is proportional to his permanent income. The hypothesis can be shortly presented as

$$
C=k Y_{p}
$$

Where $k$ denotes the MPC; $C$ represents the consumption and $Y_{p}$ is the permanent income.

The key point is that only permanent unanticipated changes in wealth will have an effect on consumption. Transitory changes in wealth have no effect on consumption. To provide empirical content to this hypothesis, Friedman added the assumptions that the transitory components are uncorrelated to each other and uncorrelated to the permanent component over time (Meghir \& Pistaferri, 2004).

\subsection{Review of Empirical Studies}

A number of literatures have argued that shocks to different from of wealth such as housing wealth and financial wealth can vary consumption responses. In fact, it is the main question in this study whether changes in different components of wealth would have the same effect to consumption. Splitting wealth into financial wealth and housing wealth in order to analyze the importance of different wealth components. One reason why the effects from housing wealth and financial wealth to consumption could be different is because house has a "dual function" (Cheng \& 
Fung, 2008) or "dual nature”(De Veirman \& Dunstan, 2008). Homeowners get a direct wealth gain whenever the rising price in housing, at the same time, the cost of consuming these housing services will rise as well (Cheng \& Fung, 2008).

The next reason because the financial wealth and housing wealth may have differences in liquidity. As mention in Dvornak and Kohler (2007) and Pissarides (1978) housing wealth is "less liquid" than financial wealth because the transaction costs in the housing market are relatively high. The other reason from the related point is that the "bequest motive" may be more important for the housing wealth, implying that households are more reluctant to sell their house. Households may have bequest motive that favor holding appreciated assets until death and may not be interested in reacting to the short-run changes in real estate values. Not only these reasons but housing wealth may also have a stronger impact on the consumption because the housing wealth tends to be "more persistent" than financial wealth.

The following studies showed that the impact of housing wealth to be much more important than financial wealth to consumption. One of the widely cited papers by Case, Quigley, and Shiller (2001) found that physical assets matter for consumption more than financial asset by used a panel data of 14 developed countries during 1975-1996. Consistence with many papers from difference countries for example the study of Carroll et al. (2006), Benjamin, Chinloy, and Jud (2004) used time series data for the United States, Pichette and Tremblay (2003) analyze the data for Canada, Ludwig, Sløk (2002) using data from 16 OECD countries. However, by using the Case et al. (2001) data set on the United States housing wealth to re-estimate the impact of the housing wealth on the non-housing consumption, the empirical study from Calomiris (2009) showed the result in different ways which housing wealth has no significant effect on the consumption. Nevertheless, some studies examine whether consumers' responses to changes in housing wealth are "asymmetric" such as Engelhardt (1996) found that an increase in housing wealth has no effect on consumption but a decline in housing wealth leads to a decline in consumption. Besides, there are the opposite results from the study of Case, et al.(2005) by using a panel of US, found that increases in housing wealth have positive and significant effects on consumption, but that declines in housing wealth have no effect. This result is supported by Dvornak and Kohler (2007) which modeled closely on the Case, et al.(2005) study but using Australian state-level data.

On the other hand, the stock market wealth also plays an important role in determining households' consumption pattern because the impact of a permanent increase in stock prices implies an increase in financial wealth, which consequently stimulates the consumer spending. The increase in stock market wealth can lead to the higher consumption either by households liquidating the appreciated stocks or by consuming the dividend stream that these assets generate, or by increasing the borrowing capacity of liquidity constrained households(Paiella, 2009). The following studies showed that the impact of stock wealth to be much more important than housing wealth to consumption, they are scattered in various countries. For example, Poterba (2000) and Sousa (2009) used data for the United States, Dvornak and Kohler (2007) used the panel data of Australian, Skudelny (2009) analyzed wealth effects on consumption for the Euro area. Although they used different methods and data, these studies found the similar conclusions that housing wealth influences consumption much less than financial wealth. Except the study of Sousa (2009) found that the housing wealth effect is statistically insignificant. The important breakthrough in Lettau \& Ludvigson (2004) is their utilization of cointegration restrictions to identify the permanent-transitory components of variations in consumption and asset wealth. They use the total sum of household net asset wealth and did not distinguish housing wealth from financial wealth. They stressed that only permanent shocks have real long run effects on consumption while transitory shocks have zero, a crucial point that has been largely neglected in previous literature. Additionally, using the same approach with Lettau and Ludvigson $(2001,2004)$ but disaggregating total wealth into housing wealth and financial wealth, Chen (2006b) found that only the shocks to housing wealth have impact on consumer spending for Swedish data, meanwhile De Veirman and Dunstan (2008) showed that both wealth components are important for consumption in New Zealand household.

\section{Methodology}

\subsection{Empirical Framework}

The methodology in this study is related to the effect of asset price fluctuation on consumption affects. The model starts from the PIH, which explain about the consumption and wealth. The standard determinants of consumption are wealth $(W)$ and permanent income $\left(Y_{p}\right)$, and the consumption function as follows:

$$
C=\alpha W+\beta Y_{p}
$$

where $\alpha$ and $\beta$ measure respectively the marginal propensity to spend out of wealth and permanent income.

The empirical estimation is not feasible because aggregate wealth includes human wealth which is unobservable. As mention by Lettau and Ludvigson (2001) that the total wealth can be thought of as the sum of financial wealth, human wealth and housing wealth 


$$
W_{t}=H_{t}+F_{t}+Y_{t}
$$

where $F_{t}$ is financial wealth, $H_{t}$ is housing wealth, $Y_{t}$ is human wealth.

When total wealth decomposed into housing wealth $\left(H_{t}\right)$ and financial wealth $\left(F_{t}\right)$, the simplest specification derived from PIH for estimating various wealth effects takes the form

$$
C_{t}=\alpha+\beta_{h} H_{t}+\beta_{f} F_{t}+B_{y} Y_{t+} \varepsilon_{t}
$$

Where $C_{t}$ stands for consumption, $H_{t}$ is housing wealth, $F_{t}$ for stock wealth and $Y_{t}$ for personal disposable income. This specification equation as is shown in Benjamin et. al (2004), Dvornak and Kohler (2007), and other studies. The coefficient $\beta_{h}, \beta_{f}$ measure the MPC out of housing wealth and stock wealth respectively.

We look at the Permanent Income Hypothesis (PIH) under uncertainty (Hall, 1978). Hall (1978) derived the implications of the rational expectations for consumption. He has argued that if expectations are rational, then the current consumption is the best predictor of future consumption. The assumption of quadratic utility led us to the following Euler equation for consumption:

$$
E\left(C_{t+1}\right)=C_{t}
$$

where $E\left(c_{t+1}\right)$ is expected future consumption, and $c_{t}$ is current consumption.

Under rational expectation, we can express future consumption as its (conditional) expectation plus an error term which (conditional) expectation is zero. That is

$$
C_{t+1}=E\left(C_{t+1}\right)+\varepsilon_{t+1}
$$

where $\varepsilon$ is the random error reflecting a surprise factor and $E_{t} \varepsilon_{t+1}=0$. Substituting (7) into (8) yield:

$$
C_{t+1}=C_{t}+\varepsilon_{t+1}
$$

where $C$ denotes the consumption, $\varepsilon$ is the random error reflecting a surprise factor and $t, t+1$ is the subscript for time.

The equation (9), it states that the best forecast for the consumption level in the next period is the current consumption. The error term, $\varepsilon_{t+1}$ is unpredictable at $t$; it is the differences between consumption at $t$ and $t+1$ $\left(\Delta C_{t} \equiv C_{t+1}-C_{t}=\varepsilon_{t+1}\right)$.

Hall (1978) tested his random walk hypothesis by regress the change in consumption on lagged income and lagged consumption. Thus, according to the random walk hypothesis, these lagged variables should have no effect on the current change in consumption since all the available information about the wealth of individuals has been incorporated into their consumption level at that moment.

Flavin (1981) retested Hall's random walk hypothesis for consumption. Flavin's model mainly focuses on the role played by current income in providing new information about future income. Thus, in order to calculate the change in expected permanent income from a change in expected current income. Flavin found that the consumption response too much to current income. This is known as "excess sensitivity". Flavin (1981) use the following consumption and income equation;

$$
\begin{gathered}
\Delta C_{t}=\gamma+\beta_{1} \Delta Y_{t}+\beta_{2} \Delta Y_{t-1}+\phi \varepsilon_{t}+\mu_{t} \\
Y_{t}=\alpha_{0}+\alpha_{1} Y_{t-1}+\alpha_{2} Y_{t-2}+\varepsilon_{t}
\end{gathered}
$$

$\varepsilon_{t}$ is unpredictable income shock. $\mu_{t}$ is the measurement error in consumption change. $\beta_{1}, \beta_{2}$ are the excess sensitivity parameters therefore if the permanent income hypothesis is valid $\beta_{1}, \beta_{2}$ should be zero. In this paper, we are following on Flavin's (1981) framework to separate the expected and unexpected components of wealth.

An empirical framework for this study follows the system of equations;

$$
\begin{aligned}
\Delta C_{t} & =\gamma_{0}+\beta_{Y} \Delta \hat{Y}_{t}+\beta_{H} \Delta \widehat{H}_{t}+\beta_{S} \Delta \hat{S}_{t}+\beta_{R} \Delta \hat{R}_{t}+\phi_{Y} \hat{\varepsilon}_{Y_{t}}+\phi_{Y} \hat{\varepsilon}_{Y_{t}}+\phi_{H} \hat{\varepsilon}_{H_{t}}+\phi_{S} \hat{\varepsilon}_{S_{t}}+\phi_{R} \hat{\varepsilon}_{R t}+\mu_{t} \\
\Delta Y_{t} & =\gamma_{1}+\sum_{j=1}^{4} \theta_{1 j} \Delta Y_{t-j}++\sum_{j=1}^{4} \theta_{2 j} \Delta H_{t-j}+\sum_{j=1}^{4} \theta_{3 j} \Delta S_{t-j}+\sum_{j=1}^{4} \theta_{4 j} \Delta R_{t-j}+\varepsilon_{Y_{t}} \\
\Delta H_{t} & =\gamma_{2}+\sum_{j=1}^{4} \delta_{1 j} \Delta Y_{t-j}++\sum_{j=1}^{4} \delta_{2 j} \Delta H_{t-j}+\sum_{j=1}^{4} \delta_{3 j} \Delta S_{t-j}+\sum_{j=1}^{4} \delta_{4 j} \Delta R_{t-j}+\varepsilon_{H_{t}} \\
\Delta S_{t} & =\gamma_{3}+\sum_{j=1}^{4} \omega_{1 j} \Delta Y_{t-j}++\sum_{j=1}^{4} \omega_{2 j} \Delta H_{t-j}+\sum_{j=1}^{4} \omega_{3 j} \Delta S_{t-j}+\sum_{j=1}^{4} \omega_{4 j} \Delta R_{t-j}+\varepsilon_{S_{t}}
\end{aligned}
$$


while $\Delta \hat{Y}_{t}, \Delta \widehat{H}_{t}, \Delta \hat{S}_{t}$ are anticipated changes, $\hat{\varepsilon}_{Y_{t}}, \hat{\varepsilon}_{H_{t}}, \hat{\varepsilon}_{S_{t}}$ are unanticipated shock in $\Delta \hat{Y}_{t}, \Delta \widehat{H}_{t}, \Delta \hat{S}_{t}$

From PIH, the main foundations of the theory it follows that only permanent unanticipated changes in wealth, either human or non-human, will have an effect on aggregate long-term trend of consumption. Transitory changes in wealth are said to have no effect on consumption. The theory indicates that consumption will respond to changes in shocks to permanent income.

\subsection{Empirical Model}

The VAR methodology is commonly used in the econometric analysis in order to find models that approximate the data generating processes of the macroeconomic time series, to understand the interactions between macroeconomic variables, and to describe the dynamic impact of random disturbances on the system of the variables (Akin, 2008). In the present analysis, has to decide which variables to include into the model by refer to economic theory or any prior studies. We follow the convention by adopting standard time-series econometrics. This study we are take a logarithmic approximation to the data equation in order to avoid heteroscedasticity problem because the average magnitude of the error term is not stable over time as argue by Campbell and Deaton (1989).

The pre step for all time- series data is the test of the cointegration analysis in order to determine whether the series is stationary or non-stationary. In our analysis we apply one of the tests for unit root- the Augmented Dickey-Fuller (ADF) test. Further that the appropriate lag length of the VAR model has to be decided. We have to determine the number of lags that are needed to capture most of the effects that the exogenous variables have on the endogenous variable. In deciding the number of lags, it has been common to use a statistical method, like the Akaike information criteria. However, a large lag length relatively to the number of observations, will typically lead to poor and inefficient estimates of the parameters. On the other hand, a too short lag length will induce spurious significance of the parameters, as unexplained information is left in the disturbance term. The approach suggested here is to use some of the statistical information criteria to select the smallest possible lag length. This paper, the VAR equation was estimated using the SBIC to find the optimal lag lengths.

Thereafter, the effect of shock on the rest of the system can be assessed through the computation of impulse responses and variance decompositions that are stimulated from the estimated VAR models. The next step in applied VAR modeling is to establish the impulse responses and the variance decomposition for characterizing the dynamic behavior of the VAR model. The VAR models are usually presented through impulse responses (that measure the effect of the different shocks on the variable of study), and variance decomposition (which measures the relative importance of the different shocks to the variation in the different variables). We use the variance decomposition for a cointegrated system to find out the relative importance of permanent and transitory shocks at different forecast horizon. Finally, forecasting performance of Variance Autoregressive models, generated from Forecast Error Variance Decompositions (FEVDs).

\section{Data}

This section of the paper looks at the data sources and the description of the variables, which use in the estimation of the stock market and housing wealth effects on consumption in Thailand at the macroeconomic level. Due to our study face a number of data limitations, therefore we use stock market indices and house price indices as proxy variables for the two wealth components. Both of housing indices and stock indices are proxy as the unanticipated changes in values that might cause households to reconsider their incomes therefore change their consumption behavior within the PIH. In addition to the explanatory variables for consumption are selected consistent with the empirical literature using the PIH.

The data set consists of quarterly data for the econometric analysis cover 1993Q1 - 2014Q2; the period of each variable is dictated by data availability. All variables are in local currencies. The basic data we use are consists of Private Consumption Expenditure (C) which taken from Office of the National Economic and Social Development Board. We use real gross domestic product (GDP) in terms of seasonally adjusted represent for disposable income. GDP is taken from Office of the National Economic and Social Development Board. Housing price index $\left(H_{t}\right)$, in the present analysis, we use two alternative housing price indices, the single houses with land (SING) and the townhouses with land (TOWN), which are published by the Bank of Thailand. For stock price, we use the Stock Exchange of Thailand Index (SET) collected from the Stock Exchange of Thailand. All these series are transformed by taking in the natural logarithm. 


\section{Empirical Results}

\subsection{Summary Statistics}

In this paper, we are following on Flavin's (1981) framework to separate the expected and unexpected components of wealth. The VAR in the first log-differenced variables is estimated using one lag or time trend. Then we perform some preliminary data analyses to verify whether I have specified the variables according to their time series properties. The dynamic effects of the different shocks on the variables are thereafter estimated.

Table 1. The result of VAR

\begin{tabular}{|c|c|c|c|c|c|c|c|}
\hline Variable & Constant & $\Delta \ln C_{t-1}$ & $\Delta \operatorname{lnGDP_{t-1}}$ & $\Delta \operatorname{lnSET} T_{t-1}$ & $\operatorname{lnTOWN}_{t-1}$ & $\Delta \operatorname{lnSING_{t-1}}$ & $\varepsilon_{t}$ \\
\hline$\Delta \ln C_{t}$ & $\begin{array}{c}0.003 \\
(0.125)\end{array}$ & $\begin{array}{c}0.1 \\
(.422)\end{array}$ & $\begin{array}{l}0.5225 \\
(0.000)\end{array}$ & $\begin{array}{c}-0.0002 \\
(0.920)\end{array}$ & $\begin{array}{c}-0.1909 \\
(0.050)\end{array}$ & $\begin{array}{l}0.0745 \\
(0.370)\end{array}$ & $\varepsilon_{1, t}$ \\
\hline$\Delta \ln G D P_{t}$ & $\begin{array}{l}0.0048 \\
(0.039)\end{array}$ & $\begin{array}{l}0.2395 \\
(0.149)\end{array}$ & $\begin{array}{l}0.3245 \\
(0.025)\end{array}$ & $\begin{array}{c}-0.0013 \\
(0.654)\end{array}$ & $\begin{array}{l}-0.133 \\
(0.306)\end{array}$ & $\begin{array}{l}0.0379 \\
(0.733)\end{array}$ & $\varepsilon_{2, t}$ \\
\hline$\Delta \operatorname{lnSET_{t}}$ & $\begin{array}{c}-0.0065 \\
(0.947)\end{array}$ & $\begin{array}{l}8.9581 \\
(0.211)\end{array}$ & $\begin{array}{c}-9.6095 \\
(0.123)\end{array}$ & $\begin{array}{c}-0.3147 \\
(0.011)\end{array}$ & $\begin{array}{c}-13.8854 \\
(0.013)\end{array}$ & $\begin{array}{l}9.8328 \\
(0.039)\end{array}$ & $\varepsilon_{3, t}$ \\
\hline$\triangle \operatorname{lnTOWN_{t}}$ & $\begin{array}{l}0.0054 \\
(0.259)\end{array}$ & $\begin{array}{c}-0.0711 \\
(0.838)\end{array}$ & $\begin{array}{l}0.2131 \\
(0.481)\end{array}$ & $\begin{array}{c}0.002 \\
(0.742)\end{array}$ & $\begin{array}{c}-0.5004 \\
(0.065)\end{array}$ & $\begin{array}{l}0.0578 \\
(0.803)\end{array}$ & $\varepsilon_{4, t}$ \\
\hline$\Delta \operatorname{lnSING} G_{t}$ & $\begin{array}{l}0.0069 \\
(0.214)\end{array}$ & $\begin{array}{c}-0.4622 \\
(0.248)\end{array}$ & $\begin{array}{l}0.3927 \\
(0.260)\end{array}$ & $\begin{array}{l}0.0069 \\
(0.318)\end{array}$ & $\begin{array}{l}0.0565 \\
(0.857)\end{array}$ & $\begin{array}{c}-0.4992 \\
(0.062)\end{array}$ & $\varepsilon_{5, t}$ \\
\hline
\end{tabular}

Table 2. Descriptive statistics of the variables

\begin{tabular}{|c|c|c|c|c|c|}
\hline STATS & $\Delta \operatorname{lnSING}$ & $\Delta \ln T O W N$ & $\Delta \operatorname{lnSET}$ & $\Delta \ln G D P$ & $\Delta \ln C$ \\
\hline Mean & 0.006 & 0.005 & -0.049 & 0.009 & 0.008 \\
\hline Median & 0.009 & 0.006 & 0.031 & 0.012 & 0.010 \\
\hline Min & -0.233 & -0.217 & -3.583 & -0.052 & -0.061 \\
\hline Max & 0.199 & 0.180 & 4.248 & 0.068 & 0.044 \\
\hline SD & 0.048 & 0.040 & 0.833 & 0.020 & 0.017 \\
\hline Skewness & -0.855 & -1.284 & 0.250 & -0.879 & -1.313 \\
\hline Kurtosis & 13.753 & 18.772 & 16.508 & 5.695 & 6.573 \\
\hline $\mathbf{N}$ & 82 & 82 & 82 & 82 & 82 \\
\hline
\end{tabular}

Table 2 shows the summary statistics for all variables. A number of points should be noted here. Mean and median of all variables are closed to each other, except for $\Delta \operatorname{lnSET}$. This shows that the data are relatively balanced. In addition, the min and max values are approximately about two standard deviations for all variables but $\Delta \ln S E T$. With respect to the skewness and kurtosis, all variables but $\Delta \operatorname{lnSET}$ show a negative skewness indicating a heavy tail to the left of the variables, meanwhile all kurtosis statistics are high which shows the a leptokurtic distribution of all variables. Overall, all variables do not have unusual characteristics, except for the $\Delta \operatorname{lnSET}$. Therefore, the winsorizing technique is applied with this variable (i.e. $\Delta \operatorname{lnSET}$ ) to check whether the estimated results are significantly changed. However, the empirical results show a slight change the winsorized level of $5 \%$ and $10 \%$. As a consequence, the original data of $\Delta \operatorname{lnSET}$ is utilized for the study. $\Delta \operatorname{lnSING}$ is the change in log of single house index; $\Delta \operatorname{lnTOWN}$ is the change in log of townhouse index., $\Delta \ln$ SET is the change in log of Stock Exchange Index; $\Delta \operatorname{lnGDP}$ is the change in $\log$ of Gross Domestic Product, $\Delta \ln C$ is the change in $\log$ of Private Consumption Expenditure. 
Table 3. Serial correlation for $\Delta \ln S I N G, \Delta \operatorname{lnTOWN}, \Delta \operatorname{lnSET}, \Delta \ln G D P, \Delta \ln C$

\begin{tabular}{|c|c|c|c|c|c|}
\hline \multirow[b]{2}{*}{ LAG } & \multicolumn{5}{|c|}{$\mathbf{A C}$} \\
\hline & $\Delta \operatorname{lnSING}$ & $\Delta \ln T O W N$ & $\Delta \operatorname{lnSET}$ & $\Delta \ln G D P$ & $\Delta \ln C$ \\
\hline 1 & $-0.420 * * *$ & $-0.405 * * *$ & $-0.256^{* *}$ & $0.411 * * *$ & $0.440 * * *$ \\
\hline 2 & $0.120 * * *$ & $0.114 * * *$ & $-0.059 *$ & $0.175^{* * *} *$ & $0.307 * * *$ \\
\hline 3 & $-0.103 * * *$ & $-0.138 * * *$ & 0.060 & $-0.062 * * *$ & $0.257 * * *$ \\
\hline 4 & $0.158 * * *$ & $0.168 * * *$ & -0.152 & $-0.013 * * *$ & $0.045 * * *$ \\
\hline 5 & $-0.130 * * *$ & $-0.066^{* * *}$ & $0.190 *$ & $0.069 * * *$ & $-0.115 * * *$ \\
\hline 6 & $0.118 * * *$ & $0.058 * * *$ & 0.012 & $0.037 * *$ & $-0.106 * * *$ \\
\hline 7 & $-0.089 * * *$ & $-0.067 * * *$ & $-0.267 * *$ & $-0.061 * *$ & $-0.069 * * *$ \\
\hline 8 & $-0.136 * * *$ & $-0.186 * * *$ & $0.119 * *$ & $-0.203 * *$ & $-0.227 * * *$ \\
\hline
\end{tabular}

Table 3 presents the Box-Pierce portmanteau test (1970) of serial correlation up to the eighth order for all variables. As can be seen the results show that all variables obviously have serial correlations up to the eighth order at $1 \%$ level, except that the result for $\Delta \operatorname{lnSET}$ is a bit unclear. However, the autocorrelation coefficient is significantly large only in the first order for all variables (i.e. about 0.4 for all and 0.2 for $\Delta \operatorname{lnSET}$ ), while from the second order backward the coefficient is very small (i.e. about 0.1 or smaller for all variables and a slightly greater for $\Delta \ln C$ ). The results seem to indicate that the model with 1 lag seems appropriate. Nevertheless, to make sure that the model is correctly specified we need to use the information criteria (e.g. AIC, HQIC and SBIC) to choose the optimal lag length for the model. *, ** and $* * *$ denote that the slope parameter estimates are statistically significant at the levels of $10 \%, 5 \%$ and $1 \%$, respectively. 2. See notes in Table 1 for variable names.

Table 4. ADF tests for stationary

\begin{tabular}{|c|c|c|c|c|}
\hline \multirow[b]{2}{*}{ Variables } & \multirow{2}{*}{ ADF test-Statistic } & \multicolumn{3}{|c|}{ Critical values } \\
\hline & & $1 \%$ & $5 \%$ & $10 \%$ \\
\hline$\Delta \operatorname{lnSING}$ & $-7.474 * * *$ & -3.551 & -2.913 & -2.592 \\
\hline$\Delta \operatorname{lnTOWN}$ & $-7.412 * * *$ & -3.551 & -2.913 & -2.592 \\
\hline$\Delta \operatorname{lnSET}$ & $-10.161 * * *$ & -3.551 & -2.913 & -2.592 \\
\hline$\Delta \ln G D P$ & $-4.831 * * *$ & -3.551 & -2.913 & -2.592 \\
\hline$\Delta \operatorname{lnC}$ & $-3.760 * * *$ & -3.551 & -2.913 & -2.592 \\
\hline
\end{tabular}

Table 4 presents the unit root test for all variables at first difference data. The Dickey and Fuller unit root test (1979, 1981), ADF test, is employed. ADF statistics is significant at $1 \%$ level for all variables which rejects the presence of unit root in first difference of all variables. $* * *$ and $* * *$ denote that the slope parameter estimates are statistically significant at the levels of $10 \%, 5 \%$ and $1 \%$, respectively. Lag length selection for the test is based on AIC, HQIC, SBIC. All tests are ADF with 1 lag and no trend.

\section{Forecast error variance decomposition}

From the estimated VAR, the log-differenced variables are estimated using one lag. We estimate Forecast error variance decomposition (FEVD) and impulse-response functions (IRF) as a basis for inferences.

Table 5. Forecast error variance decomposition of consumption

\begin{tabular}{|c|c|c|c|c|c|}
\hline Horizon & $\Delta \ln C$ & $\overline{\Delta \operatorname{lnGDP}}$ & $\Delta \ln T O W N$ & $\Delta \operatorname{lnSING}$ & $\Delta \operatorname{lnSET}$ \\
\hline \multirow[t]{2}{*}{1} & $76.43 \%$ & $17.49 \%$ & $5.42 \%$ & $0.47 \%$ & $0.20 \%$ \\
\hline & $(.0817)$ & $(.0764)$ & $(.0397)$ & $(.0104)$ & $(.0092)$ \\
\hline \multirow[t]{2}{*}{2} & $74.97 \%$ & $19.28 \%$ & $5.06 \%$ & $0.47 \%$ & $0.22 \%$ \\
\hline & $(.0849)$ & $(.0811)$ & $(.037)$ & $(.0102)$ & $(.0083)$ \\
\hline \multirow[t]{2}{*}{3} & $74.39 \%$ & $19.70 \%$ & $5.19 \%$ & $0.50 \%$ & $0.21 \%$ \\
\hline & $(.0865)$ & $(.0827)$ & $(.0381)$ & $(.0112)$ & $(.0081)$ \\
\hline \multirow[t]{2}{*}{4} & $74.17 \%$ & $19.93 \%$ & $5.17 \%$ & $0.51 \%$ & $0.21 \%$ \\
\hline & $(.0873)$ & $(.0837)$ & $(.038)$ & $(.0112)$ & $(.008)$ \\
\hline \multirow[t]{2}{*}{5} & $74.14 \%$ & $19.96 \%$ & $5.18 \%$ & $0.51 \%$ & $0.21 \%$ \\
\hline & $(.0875)$ & $(.0839)$ & $(.038)$ & $(.0114)$ & $(.0079)$ \\
\hline \multirow[t]{2}{*}{6} & $74.11 \%$ & $19.99 \%$ & $5.18 \%$ & $0.51 \%$ & $0.21 \%$ \\
\hline & $(.0876)$ & $(.084)$ & $(.038)$ & $(.0114)$ & $(.0079)$ \\
\hline
\end{tabular}


Townhouse price shocks, single house price shocks and stock price shocks explain a different share of consumption variability. Table 5 report the forecast error variance decomposition of consumption due to the shocks we consider in 6 steps horizon. The Table 5 presents how different shocks contribute to fluctuation in a given variable at forecast horizons. The variance decomposition is different from the impulse response analysis because it takes the size of the shocks into account. Forecast error variance decomposition tells how much of a change in a variable is due to its own shock and how much due to shocks to other variables.

The results indicate that disturbance originating from consumption itself caused the greatest variability to future consumption: it contributes up to 76.43 percent variability one quarter ahead, approximately 74.17 percent four steps ahead. The proportion of variance remains high (74.11 percent) even until 6 horizons. Despite an average of 74.7 percent of the variability in consumption contributed by current consumption changes, there remains 25.3 percent of the variability, which is explained by other factors. GDP shocks explain between 17 and 19 percent of the variance of consumption depending on the forecast horizons- with higher shares explained at longer forecast horizons. While, townhouse price shocks explain about $5 \%$ and single house price shocks explain about $0.47-0.51 \%$ of the variance of consumption, stock price shocks explain about $0.2-0.21 \%$ of the variance of consumption. To explaining variations of consumption, the housing market is more important than stock market.

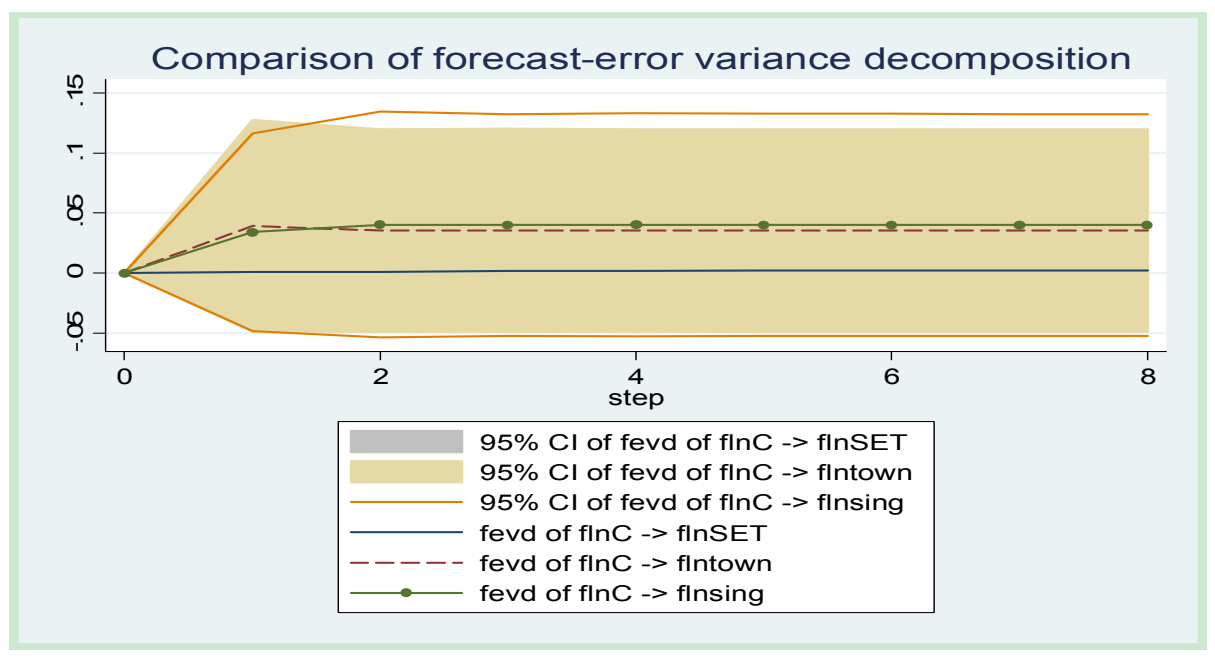

Figure 1. Comparison of forecast error variance decomposition

Impulse response analysis was conducted to examine the impact of unanticipated shocks on consumption. Figure 1 plots the response of $\Delta \operatorname{lnC}$ only to a unit shock in $\Delta \operatorname{lnTOWN}, \Delta \operatorname{lnSING}$ and $\Delta \ln$ SET. The result shows that a unit shock in $\triangle \operatorname{lnTOWN}$ and $\Delta \operatorname{lnSING}$ has stronger impact than a unit shock in $\Delta \operatorname{lnSET}$ on consumption. The vertical axis represents deviation of variables. The horizontal axis indicates the time that has passed in quarters.

We are interested in analyzing and comparing between the financial wealth shock and housing price shock to consumption. The effect of change in housing wealth to consumption should be larger than that of changes in other assets, such as stocks, because housing wealth is held by a larger proportion of households. Residential and commercial real estate are account for more than one thirds of total asset in Thailand. This pattern is consistent with international data, in that real estate accounts for a large portion of household assets in most countries. Bertaut, Starr-McCluer (2002) shows that real estate accounts for $25 \%$ of aggregate US household wealth and Banks and Tanner (2002) shows that real estate accounts for $35 \%$ of aggregate UK household wealth. This pattern is consistent with the World Bank's World Develop Indicator Database which reports home ownership rates for five countries between 1999-2001; Thailand (81\%), Nepal (81\%), the Philippines (83\%), Sri Lanka (70\%) and Vietnam (95\%). In the same period, the database also shows the corresponding for the U.K. and the U.S at $66 \%$ and $57 \%$ respectively (Nakornthab, Research, \& Centre, 2010). We can also imply that the high debt to financial asset ratios can reflect in the tendency for household to have the most proportion of their assets in the form of real assets, of which the majority are real estates (Nakornthab, et al., 2010). In terms of the composition of household debt, Graph3 show that real estate also account for a large part of household debt (3.7\%) in 2006 and (4.6\%) in 2010 the same as consumption (3.9\%) in 2006 and (4.3\%) in 2010. The large share of real estate in the asset and debt portfolios in Thai's households indicates that the households are likely to have strong impact on house price shock. The current structure of total assets indicates that Thai households still rely invest more in terms of real estate than on capital markets. This is consistent with the result that housing wealth shock has more impact to consumption than stock price shock. Although variance decomposition by the estimate of the proportion of consumption variance accounted its determinants, it cannot indicate whether the impact is positive or negative, or whether it is a temporary jump or 
long-run persistence. Thus, impulse response functions are computed to examine the impact of unanticipated shocks on consumption from disposable income, stock price index, and housing price index to consumption.

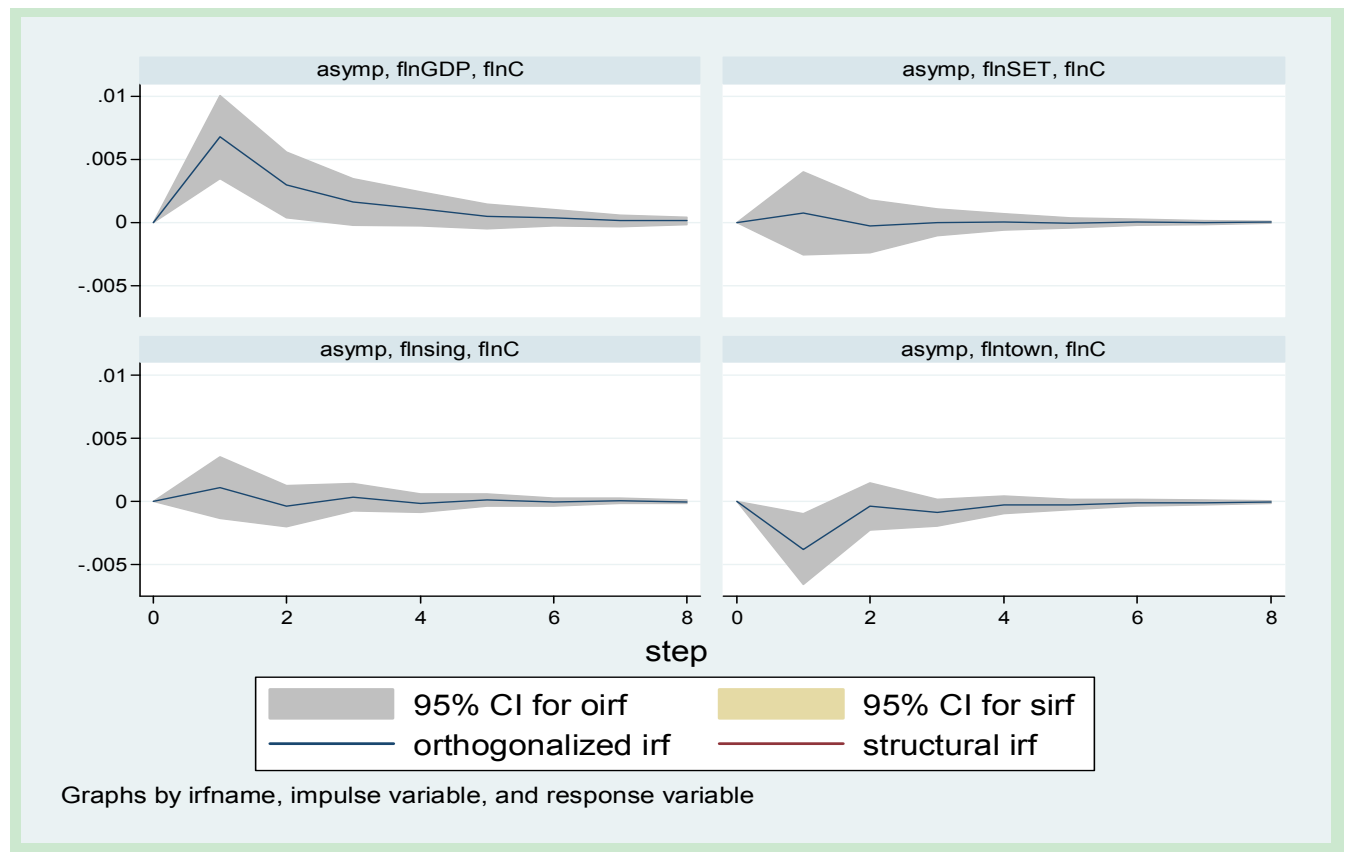

Figure 2. Impulse response analysis to consumption

Figure 2 illustrates the estimated impulse response functions for 8 quarters by plotting the impulse response functions. It is a method to visually represent the behavior of the GDP, stock price index, and housing price index in shocks to the consumption response. The upper left panels of Figure 1 show the response of GDP. Not surprisingly, consumption significantly responds to unanticipated changes in disposable income. The response of consumption to an impulse in unanticipated change in stock prices is graphed in the upper right panels of Figure 1. While the effects of single house prices are depicted in the lower left panels, and the effects of town house prices are depicted in the lower right panels. The vertical axis represents deviation of variables. The horizontal axis indicates the time that has passed in quarters.

In response to a one standard deviation disturbance in GDP, GDP reaches a maximum about 1 quarter after the initial GDP shock to the economy. In the first quarter, future GDP becomes 52\% and it appears to die out in 4 quarters ahead. It is implying that the GDP change has a greater influence on consumption in the next quarter rather than over longer-term horizon. In fact, the response of consumption to stock prices is rather muted. Stock price index has a small positive effect on consumption as expected. Its greatest positive effect $(0.048 \%)$ occurs in the second quarter. The results from the impulse response analyses imply that the two kinds of house induce the different results. While, the single houses induce the positive wealth effect overtime but the town houses induce the negative wealth effect in the first quarter. A one standard deviation disturbance originate from single house price index result in an approximately $7 \%$ in change in consumption. It has a small positive impact $(7.4 \%)$ in the first quarter and in the second quarter has a very small negative impact $(2.3 \%)$. Then, it dies out very fast in the next 4 quarter ahead. Further, the effects from changes in townhouse prices are more persistent, particularly in the first period. In response to a one standard deviation shocks to townhouse price index, future townhouse price index decreases by $19 \%$ in the first quarter. This appears to die out very quickly after two quarters, implying that the townhouse price index change has a greater influence on consumption in the next quarter rather than over longer-term horizon.

There are many reasons why single house price and town house price shocks have different impact to consumption. While the shock from single house prices moves together with the consumption, town house price shocks move in the opposite direction. The differences in the tenure patterns of the two kinds of house may help explain the results. What are the implications of a high owner-occupation rate between single house and town house? Because there are the fewer wealthier owner-occupiers in the town house segment than the single house sector, an increase in the town house prices will diminish the ability of consumption.

In addition as mention above, the ratio of debt to assets is higher for low income than for high income households, suggesting that the low income household more sensitive to the shocks. The housing price shocks could force lower income households to reduce the consumption (Subhanij, 2009). This is consistent with the result while the increase 
in town house prices induce consumption decreasing, an increase in single house prices may move together with consumption. The other reason because a rise in house prices leads to the effective cost of borrowing or a rate on a mortgage increase, household will have higher interest payments then they have to reduce consumption.

Unlike other assets, housing has a dual role of being both a store of wealth and an important durable consumption good. A shock to house prices may therefore affect the wealth of homeowners. Fluctuations in house prices significantly affect the value of houses as collateral and therefore strongly influence borrowing conditions for households. Fluctuations in house prices significantly affect the value of houses as collateral and therefore strongly influence borrowing conditions for households. As the value of collateral rises, this will also increase the availability of credit for borrowing-constrained agents.

On the other hand, the homeowner of single-house may also have a direct impact on consumption via credit market effects. Houses represent collateral for homeowners. So an increase in house prices makes more collateral available to homeowners, which in turn may encourage them to borrow more, in the form of mortgage equity withdrawal (MEW), to finance desired levels of consumption. Higher house prices can also have the effect of relaxing credit constraints. Homeowners have additional collateral against which they can borrow when the house price rise. This provides a channel through which rising house prices can stimulate consumption spending such as the empirical study about the direct role in determining spending by Greenspan and Kennedy (2005), Benito et al (2006).

The scope for homeowner in Thailand to borrow against housing collateral may increase overtime. Currently, commercial banks and the Government Housing Bank (GHB) are the two dominant mortgage lenders with a combined share of $80-90 \%$. The GHB is the leading mortgage financial institution with a market share of $39 \%$ of all residential mortgages. In the UK, it has been argued that developments in the financial sector made housing wealth more fungible, allowing households to access their housing equity for consumption (Miles, 1994). Similarly, a decrease in liquidity constraints in Thailand may allow homeowners to access housing equity for financing future consumption.

\section{References}

Akin, C. (2008). Housing market characteristics and estimation of housing wealth in Turkey.

Banks, J., \& Tanner, S. (2002). Household portfolios in the United Kingdom (Vol. 6): chapter.

Bayoumi, T., \& Edison, H. (2003). Is wealth increasingly driving consumption?. De Nederlandsche Bank.

Benito, A., Mumtaz, H., \& England, B. o. (2006). Consumption excess sensitivity, liquidity constraints and the collateral role of housing. Bank of England.

Benjamin, J. D., Chinloy, P., \& Jud, G. D. (2004). Real estate versus financial wealth in consumption. The Journal of Real Estate Finance and Economics, 29(3), 341-354. http://dx.doi.org/10.1023/B:REAL.0000036677.42950.98

Bertaut, C. (2002). Equity prices, household wealth, and consumption growth in foreign industrial countries: wealth effects in the 1990s.

Calomiris, C., Longhofer, S. D., \& Miles, W. (2009). The (mythical?) housing wealth effect. National Bureau of Economic Research. http://dx.doi.org/10.3386/w15075

Campbell, J. Y., \& Cocco, J. (2005). How do house prices affect consumption? Evidence from micro data. National Bureau of Economic Research Cambridge, Mass., USA. http://dx.doi.org/10.3386/w11534

Campbell, J. Y., \& Mankiw, N. G. (1989). International evidence on the persistence of economic fluctuations. Journal of Monetary Economics, 23(2), 319-333. http://dx.doi.org/10.1016/0304-3932(89)90054-8

Caporale, G., \& Sousa, R. (2011). Consumption, wealth, stock and housing returns: evidence from emerging markets.

Carroll, C. D., Otsuka, M., \& Slacalek, J. (2006). How large is the housing wealth effect? A new approach. National Bureau of Economic Research. http://dx.doi.org/10.3386/w12746

Carroll, C. D., Otsuka, M., \& Slacalek, J. (2011). How large are housing and financial wealth effects? A new approach. Journal of Money, Credit and Banking, 43(1), 55-79. http://dx.doi.org/10.1111/j.1538-4616.2010.00365.x

Case, K. E., Quigley, J. M., \& Shiller, R. J. (2001). Stock market wealth, housing market wealth, spending and consumption.

Case, K. E., Quigley, J. M., \& Shiller, R. J. (2005). Comparing wealth effects: the stock market versus the housing market. The BE Journal of Macroeconomics, 5(1), 1.

Chen, J. (2006a). Housing Wealth and Aggregate Consumption in Sweden. Uppsala University Economics Working Paper No. 2006: 16. 
Chen, J. (2006b). Re-evaluating the association between housing wealth and aggregate consumption: New evidence from Sweden. Journal of Housing Economics, 15(4), 321-348. http://dx.doi.org/10.1016/j.jhe.2006.10.004

Cheng, A. C. S., \& Fung, M. K. (2008). Financial market and housing wealth effects on consumption: a permanent income approach. Applied Economics, 40(23), 3029-3038. http://dx.doi.org/10.1080/00036840600994021

Contreras, J., \& Nichols, J. (2009). Consumption responses to permanent and transitory shocks to house appreciation.

De Veirman, E., \& Dunstan, A. (2008). How do housing wealth, financial wealth and consumption interact? Evidence from New Zealand. Reserve Bank of New Zealand Discussion Paper Series.

Dvornak, N., \& Kohler, M. (2007). Housing Wealth, Stock Market Wealth and Consumption: A Panel Analysis for Australia. Economic Record, 83(261), 117-130. http://dx.doi.org/10.1111/j.1475-4932.2007.00388.x

Engelhardt, G. V. (1996). House prices and home owner saving behavior. Regional Science and Urban Economics, 26(3-4), 313-336. http://dx.doi.org/10.1016/0166-0462(95)02118-3

Flavin, M. A. (1981). The adjustment of consumption to changing expectations about future income. The Journal of Political Economy, 974-1009. http://dx.doi.org/10.1086/261016

Friedman, M. (1957). The permanent income hypothesis. Princeton University Press.

Greenspan, A., \& Kennedy, J. (2005). Estimates of home mortgage originations, repayments, and debt on one-to-four-family residences. FEDS Paper No. 2005-41.

Hall, R. (1978). Stochastic implications of the life cycle-permanent income hypothesis: theory and evidence. NBER Working Paper No. R0015.

Hui, H. (2009). The impact of property market developments on the real economy of Malaysia. International Research Journal of Finance and Economics, (30).

Ibrahim, M. H., Padli, J., \& Baharom, A. (2009). Long-Run Relationships and Dynamic Interactions between Housing and Stock Prices in Thailand. Asian Academy of Management Journal of Accounting and Finance, $5(1)$.

Lettau, M., \& Ludvigson, S. (2001). Consumption, aggregate wealth, and expected stock returns. The Journal of Finance, 56(3), 815-849. http://dx.doi.org/10.1111/0022-1082.00347

Lettau, M., \& Ludvigson, S. (2004). Understanding trend and cycle in asset values: Reevaluating the wealth effect on consumption. National Bureau of Economic Research.

Ludwig, A., \& Sløk, T. (2004). The relationship between stock prices, house prices and consumption in OECD countries. The BE Journal of Macroeconomics, 4(1), 4.

Ludwig, A., Sløk, T., \& Dept, I. M. F. R. (2002). The impact of changes in stock prices and house prices on consumption in OECD countries. International Monetary Fund.

Meghir, C., \& Pistaferri, L. (2004). Income variance dynamics and heterogeneity. Econometrica, 72(1), 1-32. http://dx.doi.org/10.1111/j.1468-0262.2004.00476.x

Nakornthab, D., Research, S.-E. A. C. B., \& Centre, T. (2010). Household Indebtedness and Its Implications for Financial Stability. South-East Asian Central Banks, Research and Training Centre.

Paiella, M. (2009). The stock market, housing and consumer spending: a survey of the evidence on wealth effects. Journal of Economic Surveys, 23(5), 947-973. http://dx.doi.org/10.1111/j.1467-6419.2009.00595.x

Pichette, L., \& Tremblay, D. (2003). Are Wealth Effects Important for Canada?. Bank of Canada.

Pissarides, C. A. (1978). Liquidity considerations in the theory of consumption. The Quarterly Journal of Economics, 279-296. http://dx.doi.org/10.2307/1884163

Poterba, J. M. (2000). Stock market wealth and consumption. The Journal of Economic Perspectives, 14(2), 99-118. http://dx.doi.org/10.1257/jep.14.2.99

Richupan, S. (1999). Macroeconomic Instability and Housing Finance: Thailand's Experience. Housing Finance International, 14(2), 26-35.

Sousa, R. M. (2009). Wealth effects on consumption: evidence from the euro area. Working Paper Series.

Subhanij, T. (2009). Household sector and monetary policy implications: Thailand's recent experience. Bank for International Settlements Communications CH 4002 Basel, Switzerland, 136. 